\title{
The Internal Logic and New Thoughts of Sinicization of Marxism
}

\author{
Wang Hui \\ School of Politics and Sociology, Xianyang Normal University, Shaanxi, China, 712000
}

Keywords: Marxism; Sinicization; Internal mechanism

Abstract: Comrade Mao Zedong combined Marxism with China's reality, carried out the first revolution led by the Party and established the People's Republic of China. On the basis of practice, Marxism has made a qualitative leap in China and formed Mao Zedong Thought. On this basis, Deng Xiaoping continuously promoted the second combination of Marxism in China under the new historical conditions, and successfully realized its second qualitative leap. Deng Xiaoping can promote the second combination of Marxism in China, the key is that he follows certain internal mechanism. This study analyses the theoretical basis and realistic background of communists' promotion of the Sinicization of Marxism, and deeply studies the internal mechanism of communists' promotion of the Sinicization of Marxism.

Communists promotion of the localization of Marxism in China is not based on imagination or confusion of thoughts, but on a certain theoretical basis and realistic background, with the internal mechanism of this process as a breakthrough point, The whole process are interlinked, interacted and jointly promoted. This process is also a logical evolution from perceptual knowledge to rational knowledge, and forms objective laws. Studying the internal mechanism of this process can clarifies the internal law and logical line of communists pushing forward the Sinicization of Marxism.

\section{Sinicization of Marxism}

The localization of Marxism in China refers to the combination of the basic principles of Marxism with the actual situation of Chinese revolution and construction, so as to arrive at a socialist revolution and construction road suited to China's national conditions. It has two connotations: one is to use Marxism to solve the difficult problems encountered in China's own road to building a socialist country; the other is to accumulate experience (both old and new, positive and negative) constantly in the process of solving the difficult problems, and to summarize and sublimate it with the method of Marxism, so as to upgrade it to a higher level of theory and practice. The localization of Marxism in China is a huge theoretical system, which needs a process of continuous development, improvement and innovation.

It is mainly manifested in the new democratic revolution carried out by the Communists of China represented by Mao Zedong, the establishment of a new China and the exploration of socialist construction; the second generation of leaders with Deng Xiaoping as the core, revolving around what is socialism and how to build socialism, initiated contemporary Chinese Marxism; and the 
leading collective of the Party Central Committee represented by Jiang Zemin, revolving around what is socialism and how to build socialism. What kind of party, how to build the party; Hu Jintao as the representative of the leading collective of the CPC Central Committee, around what is the scientific development, how to develop the problem. The practice and the theory formed around these themes are to continuously promote the integration and development of Marxism in China. Since the Eighteenth National Congress, the leading collective of the CPC Central Committee, represented by General Secretary Xi Jinping, has continued to advance this development process in depth. As shown in Table 1.

Table 1. The localization of Marxism in China is a huge theoretical system

\begin{tabular}{|l|l|}
\hline $\begin{array}{l}\text { the Communists of China } \\
\text { represented by Mao Zedong }\end{array}$ & $\begin{array}{l}\text { the establishment of a new China and the } \\
\text { exploration of socialist construction }\end{array}$ \\
\hline $\begin{array}{l}\text { the second generation of leaders with } \\
\text { Deng Xiaoping as the core }\end{array}$ & $\begin{array}{l}\text { What is socialism and how to build socialism, } \\
\text { initiated contemporary Chinese Marxism }\end{array}$ \\
\hline $\begin{array}{l}\text { the leading collective of the Party } \\
\text { Central Committee represented by } \\
\text { Jiang Zemin }\end{array}$ & what is socialism and how to build socialism \\
\hline $\begin{array}{l}\text { the third generation of leaders with } \\
\text { Hu Jintao as the core }\end{array}$ & What kind of development and how to develop \\
\hline
\end{tabular}

\section{Intrinsic Logic}

The intrinsic mechanism refers to the interaction among the elements or links of things and their specific development and internal relations in the process of space form and time. Therefore, the internal mechanism has the characteristics of blending, expanding and integrity. Marxism is a scientific system with internal logical connections. Its internal principles, laws and categories are interwoven and interrelated. Engels believed that the internal logic of the sinicization of Marxism should be the theoretical expression of the rich historical process of sinicization of Marxism: "where ceremony begins and where the ideological process should begin." Its "internal logic" structure consists of "theoretical logic", " thematic logic" and " process logic". It is an organic and unified whole and systematically answers the basic questions such as the scientificalness and historical inevitability, social function and value goal, realization approach and operability of Marxism in China.

\section{Marxism Itself has the Theoretical Quality of Keeping Pace with the Times}

Marxism emphasizes the dialectical view of problems, seeks the innovation and development of theory in the long course of time, links with reality, and regards the people as the main body of development. These advanced theoretical thoughts have prepared the conditions for the localization of Marxism in China.

Marxism has the characteristics of keeping pace with the times. It reveals the essence of human social development. It is generally believed that it is the truth of scientific development and can be used to solve the phenomena occurring in all societies. But this does not mean that Marxism is unchanged and always conservative. It changes with the continuous development of social economy, with time and place as the transfer, changing with time and adapting to local conditions.In China's revolutionary construction, Chairman Mao put forward the seeking truth from facts, which made the 
Chinese Red Army of Workers and Peasants make strategic progress and ultimately realize the establishment and development of New China. In the process of China's development, Deng Xiaoping proposed emancipating the mind and seeking truth from facts has always been the main development strategy of the country. Only by seeking truth from facts can all work produce practical value and not be divorced from the social development pattern of our country. It can be said that it is these advanced theories that enable Marxism to play a role in promoting social development in China. This is the basis of its own conditions for the Sinicization of the theory.

\section{The Realistic Background of Promoting the Sinicization of Marxism}

China's historical events have provided important practical support for the in-depth use of Marxism. It can be said that in some special national conditions, the theoretical guidance of Marxism is an important source of creating correct decision-making. In the process of modern development in our country, innovation has been continuing, but its direction is clear but few, and eventually only a batch of people fall into the cause of innovative undertaking for national development. However, in the period of revolutionary, under the guidance of Marxism, the Communist Party of China decided to explore the development strategy in line with China's national conditions, and eventually formed the trend of "Start a prairie fire". When Mao Zedong led the revolutionary armed struggle in China, many people believed that we should copy the Soviet model and adopt the strategic thinking from the city to the countryside.However, Mao Zedong and others used the Marxism to make dialectical analysis and concluded that we should adjust it according to China's national conditions and eventually create the strategic idea of encircling the cities in the countryside, which is also an important theoretical support for our Party's liberation of the Chinese people.

This is to use dialectical thinking to look at the relationship between redemption cost and national stability, to recognize the essence of things, and to firmly implement the correct policy. During the period of reform and opening up, Deng Xiaoping put forward the great strategic policy of "one country, two systems" according to China's actual conditions, making important contributions to the reunification of the motherland, which is also an important manifestation of marxism to China's conditions. It can be said that in some special stages of development in China, "Marxist Sinicization" can always make use of the perspective of dialectical development to produce tremendous social benefits in Chinese society.

\section{Enlightenment from the Internal Mechanism of Promoting the Sinicization of Marxism}

Marxism is not only an important ideological principle for us to build socialism from the reality of China, but also a weapon for us to strengthen our socialist beliefs and provide ideological and theoretical weapons for constantly solving new problems raised in practice. During Deng Xiaoping's period of build socialism with chinese characteristics, Marxism made periodic progress. From learning from Marxism to using it in combination with practice, and then summarizing and sublimating Marxism, the internal mechanism of its development has promoted its further adaptation to China's development. Therefore, in the new era, Deng Xiaoping's internal mechanism of advancing the process of Marxism has important reference significance and Enlightenment for us to continue to promote the development of Marxism in China, constantly enrich the theoretical system of socialism with Chinese characteristics, and for China's development. As shown in figure 1. 


\section{The first step in Deng Xiaoping's internal mechanism of promoting}

Correctly grasp the basic national conditions at the primary stage and solve new problems from facts and facts

Persist in the Combination of Theory and Practice and Continuously Promote the Sinicization of Marxism

Figure 1. From the Internal Mechanism of Promoting the Sinicization of Marxism

\subsection{The First Step in Deng Xiaoping's Internal Mechanism of Promoting}

The Sinicization of Marxism is to learn Marxism in a correct way, which is the premise and foundation of other links. This requires us to study the theoretical achievements of Marxism and its localization in a correct way. The two theoretical achievements of the Sinicization of Marxism are Mao Zedong Thought and the theoretical system of socialism with Chinese characteristics.

\subsection{Correctly Grasp the Basic National Conditions at the Primary Stage and Solve New Problems from Facts and Facts}

Accurately grasping communists' internal mechanism of advancing the Sinicization of Marxism enlightens us to follow the law of historical development, proceed from reality and seek truth from facts to solve new problems in development. Deng Xiaoping's practical experience in promoting the Sinicization of Marxism inspires us to recognize that our country is still in the primary stage of socialism, so as to correctly analyze the development problems in the new period of reform and opening up.

\subsection{Persist in the Combination of Theory and Practice and Continuously Promote the Sinicization of Marxism}

Communists' internal mechanism of advancing the localization of Marxism in China is of great significance to the development of the new era, which enlightens us to combine theory with practice and promote the localization of Marxism in China. The reason why Marxism is scientific is that its arguments and expositions are based on facts, adhere to the combination of theory and practice, rather than divorce from reality for empty talk and nonsense.

Under the new historical conditions and new situations, the new generation of Party Central Committee, with Xi Jinping as its general secretary, has put forward the strategic layout of "four comprehensive aspects". From Deng Xiaoping's proposal of building a well-off society in the 1970s and 1980s, reform and opening-up, legal system construction and Party building to the proposal of "four comprehensiveness" put forward by the Party Central Committee with Xi Jinping as its general secretary today, the development and change of these four themes are based on practice, according to the new characteristics of the national conditions and the new circumstances of the environment, and constantly enriching and completing the theory of socialism with Chinese characteristics. 


\section{Conclusion}

Through this study, we summarize the value of Marxism in China, especially Mao Zedong and Deng Xiaoping s Contribution to Promoting the Sinicization of Marxism, and the advanced nature of Marxism itself, which are the strong support points for the application of this theory. It should be noted that in the future development process, it is still necessary to combine theory with practice, constantly innovate and optimize, and combine the special national conditions and social status of our country, to find out the theoretical guidance mechanism in line with national development.

\section{References}

[1] Chen Izhevsk. The Internal Logic of the Chinese Dream and the Sinicization of Marxism [J] Journal of Xuzhou University, 2015 (02): 5-8

[2] Li Weigh. An Analysis of the Internal Mechanism of the Formation of the Achievements of Marxist Sinicization Theory [J] Ten Years of Speed Reading, 2016 (10)

[3] Henge Ru. The Logical Context of the Sinicization of Marxism since the Reform and Opening-up [J]. Journal of Nanjing Audit Institute, 2009 (1).

[4] Thu Varying. On the Formation and Significance of the Marxist Scientific Learning View of the Communist Party of China [J].Journal of University, 2011 (4).

[5] Chou Bu. Seeking truth from facts is the ideological basis of Marxism [J]. Journal of Beijing Institute of Electronic Science and Technology, 2002(1). 